\title{
IAMJ
}

INTERNATIONAL

AYURVEDIC

MEDICAL JOURNAL

Research Article

ISSN: $2320-5091$

Impact Factor: 6.719

\section{A CLINICAL COMPARATIVE STUDY ON MANAGEMENT OF GRIDHRASI (SCIATICA) WITH RASNA GUGGULU AND TRAYODASHANG GUGGULU}

\author{
Prachi Chaudhary $^{1}$, Suryanshu Dutt Sharma ${ }^{2}$, Sriram Chandra Mishra ${ }^{3}$ \\ ${ }^{1}$ PG scholar, ${ }^{2}$ Associate Professor, ${ }^{3}$ Professor \& H.O.D, \\ P.G. Dept. of Kayachikitsa, Vaidya Yagya Dutt Sharma Ayurveda Mahavidyalaya, Khurja, Bulandshahar (U.P.) \\ India
}

Corresponding Author: prachi10chaudhary@gmail.com

\section{https://doi.org/10.46607/iamj0309022021}

(Published online: February 2021)

Open Access

(C) International Ayurvedic Medical Journal, India 2021

Article Received: 17/01/2021 - Peer Reviewed: 26/01/2021 - Accepted for Publication: 01/02/2021

Check for updates

\section{ABSTRACT}

Gridhrasi (Sciatica) is a crippling ailment cause pain in the lower back that spreads to the hip, buttocks and leg along the route of sciatic nerve. It is a major health problem related to locomotor system. Many experience symptoms of recurrence and function limitations. A clinical comparative study was done on management of Gridhrasi with Rasna Guggulu and Trayodashang Guggulu to evaluate its therapeutic efficacy. The study concludes that the Percentage (\%) of improvement shows both the trial drugs have reduced the symptoms but it was more in Trayodashang Guggulu (40\%) than Rasna Guggulu (20\%).

Keywords: Gridhrasi, Sciatica, Rasna Guggulu, Trayodashang Guggulu

\section{INTRODUCTION}

Gridhrasi (Sciatica) ${ }^{l}$ is a crippling ailment cause pain in the lower back that spreads to the hip, buttocks and leg along the route of sciatic nerve. As Gridhrasi is enumerated under eighty types of Nanatmaja Vata Vyadhis, the etiological factors of Vatavyadhi like trauma on lumbosacral spine (Abhighata), postural defects (Vishamachesta), overloading (Bharavahana), abrupt unbalanced actions (Atichesta), non-stop jerky movement etc are viewed as causative elements of the disease $^{2}$. The predominance of Vata Dosha or Vata- 
Kapha Dosha in the Samprapti (pathogenesis) of Gridhrasi leads to the manifestation of specific symptoms. The common symptoms of Gridhrasi are pain starts from Sphik (buttock) and radiating to KatiPrushta (lumbosacral region), Uru (thigh), Janu (knee), Jangha (calf), and Pada (foot) along with Stambha (stiffness), Toda (pricking pain), Spandana ${ }^{4}$ (twitching) and leads to Sakthiutkshepa Nigraha ${ }^{5}$ (restricted movement of lifting of the leg). Whereas in Vata Kaphaja type of Gridhrasi, additional symptoms like Arochaka (aversion to food), Tandra (feeling of drowsiness) and Gaurava (feeling of heaviness) are found.

So far therapy of Gridhrasi, drug of desire should have Vatashamaka, Kaphashamaka, Vatanulomaka, Dipana-Pachana (digestive-carminative), and Shulaprashamana properties. Among shaman medicines Rasna Guggulu 6 and Trayodashang Guggulu mentioned in Bhaishajya Ratnavali wherein the disease Gridhrasi has also been listed as one of the indications of this formulation. These are Guggul based herbal formulations having anti-inflammatory and analgesic properties. Hence provides strength to the nerves, bones, joints, muscles and ligaments. These properties might also easily reverse the pathogenesis of Gridhrasi. Here, to consider the efficacy, this clinical comparative study was done on management of Gridhrasi with Rasna Guggulu and Trayodashang Guggulu.

\section{Material and Methods}

Patients of both sex, and age between 20 and 70 years, having signs and symptoms of disease Gridhrasi (Sciatica) and fulfilling inclusion criteria were selected and registered for the study. The study was conducted at P.G. Dept. of Kaya Chikitsa, V.Y.D.S Ayurved Mahavidyalaya, Khurja, after getting ethical clearance from Institutional Ethics Committee vide letter No. 2017/IEC/21 Dt 17/02/201. All screened patients were divided into two groups, Group - A (TGI) treated with Rasna Guggulu and Group - B (TGII) treated with Trayodasanga Guggulu.

- Study Design -

$\rightarrow$ TGI(BT) vs. TGI(AT) - Effectiveness of treatment group - A will be assessed $\rightarrow$ TGII (BT) vs. TGII (AT) - Effectiveness of treatment group - B will be assessed

$\rightarrow$ TGI (AT) vs. TGII (AT) - Assess the comparison on effectiveness of treatment

\section{- Criteria for diagnosis}

$\rightarrow$ Positive SLR test in the affected leg

$\rightarrow$ Patients having cardinal features of the disease such as presence of dull or piercing pain, twitching and stiffness in back, lumber region, buttock, thigh, back of knee, calf, feet area in successive order.

- Inclusion criteria

$\rightarrow$ Age - In between 20 and 70 years of age

$\rightarrow$ Sex - Both Male and Female

$\rightarrow$ Patient having Pratyatmalakshana (Sign \& Symptoms) of Gridhrasi (Sciatica) as described in subjective and objective parameters below.

$\rightarrow$ Patients having positive SLR test $\left(>30^{\circ}\right)$ on examination.

\section{- Exclusion criteria}

$\rightarrow$ Patients age below 20 and above 70 years

$\rightarrow$ Positive SLR test of $<30^{\circ}$

$\rightarrow$ Traumatic conditions, Infective conditions (T.B. etc.), Neoplastic conditions, congenital deformities of spine, fibrosis of sacral legion, Tumour/SOL of cauda-equina.

$\rightarrow$ Diabetic, HIV or Cases having medical emergencies

$\rightarrow$ Pregnant and lactation cases

- Laboratory investigations -

$\rightarrow$ Routine Haematological, Urine and Biochemical investigations were carried out whenever required to exclude the possibility of any other disease as well as to know the present condition of the patients.

$\rightarrow$ Radiological assessment (X-ray L.S. spine, AP \& lateral view) were carried out in patients where necessary to ascertain the diagnosis as well as the differential diagnosis

- Posology - In Group - A (TGI), One tablet (each $500 \mathrm{mg}$ ) of Rasna Guggulu was administered orally, twice a day, after meal with lukewarm water for 30 days and in Group - B (TGII) Two tablets (each $500 \mathrm{mg}$ ) of Trayodasanga Guggulu ${ }^{7}$ was 
administered orally, twice a day, after meal with lukewarm water for 30 days.

- Duration of Treatment - One month

- Criteria for assessment - All the data were analyzed statistically by calculating the Mean, percentage of improvement, Standard Deviation, Standard Error and t-value. Subjective parameters were analysed by using the Wilcoxon matched-pairs test whereas objective parameters were analysed by using Paired' $t$ ' test. The comparisons of effects on different parameters of both drugs were analyzed statistically by using Mann-whitney test in subjective parameters and Unpaired $\mathrm{t}$ - test in objective parameters. The improvement was assessed on the presence of Subjective as well as Objective Criterias after treatment basing on Special scoring pattern as below.

\begin{tabular}{|c|c|c|}
\hline \multicolumn{3}{|c|}{ Assessment criteria for Subjective parameters } \\
\hline \multirow{4}{*}{$\begin{array}{l}\text { Low back pain radiating to foot either } \\
\text { left / right / both (Sphik Purva Kati } \\
\text { Pristha Uru Janu Jangha Pada Kramat) }\end{array}$} & Go & No pain in lumber region \\
\hline & $\mathbf{G}_{1}$ & Pain in lumber region but not radiates \\
\hline & $\mathbf{G}_{\mathbf{2}}$ & Radiating pain with slight difficulty in working \\
\hline & $\mathbf{G}_{\mathbf{3}}$ & Radiating pain with severe difficulty in working \\
\hline \multirow[t]{4}{*}{ Stiffness (Stambha) } & G0 & No stiffness \\
\hline & $\mathbf{G}_{1}$ & Mild (present only in morning) \\
\hline & $\mathbf{G}_{2}$ & Moderate (very often) \\
\hline & G3 & Severe (throughout the day) \\
\hline \multirow[t]{4}{*}{ Pricking sensation (Toda) } & $\mathbf{G}_{0}$ & No Pricking Sensation \\
\hline & $\mathbf{G}_{1}$ & Mild Pricking Sensation on off \\
\hline & $\mathbf{G}_{2}$ & Moderate Pricking Sensation very often \\
\hline & $\mathbf{G}_{3}$ & Severe Pricking Sensation throughout the day \\
\hline \multirow[t]{4}{*}{ Twitching (Spandana) } & $\mathbf{G}_{0}$ & No Twitching \\
\hline & $\mathbf{G}_{1}$ & Occasionally discontinued Twitching (on off) \\
\hline & $\mathbf{G}_{\mathbf{2}}$ & Very often Twitching \\
\hline & $\mathbf{G}_{3}$ & Persistent continued Twitching (Daily throughout the day) \\
\hline \multirow[t]{4}{*}{ Heaviness (Gauravata) } & $\mathbf{G}_{0}$ & No heaviness \\
\hline & $\mathbf{G}_{1}$ & Mild heaviness with no difficulty in working \\
\hline & $\mathbf{G}_{\mathbf{2}}$ & Heaviness with slight difficulty in working \\
\hline & $\mathbf{G}_{3}$ & Heaviness with severe difficulty in working \\
\hline \multirow[t]{4}{*}{ Numbness (Suptata) } & $\mathbf{G}_{0}$ & No numbness \\
\hline & $\mathbf{G}_{1}$ & Mild numbness can easily move the leg \\
\hline & $\mathbf{G}_{2}$ & Difficulty in moving leg $\&$ foot \\
\hline & $\mathbf{G}_{\mathbf{3}}$ & Cannot move the leg or foot \\
\hline \multirow{4}{*}{$\begin{array}{l}\text { Straight leg rising test } \\
\text { (SLR / Saktiakshapa nigraha) }\end{array}$} & $\mathbf{G}_{\mathbf{0}}$ & $>70^{\circ}($ Normal $)$ \\
\hline & $\mathbf{G}_{1}$ & $51-70^{0}$ (Mild form) \\
\hline & $\mathbf{G}_{2}$ & $30^{0}-50^{0}$ (Moderate form) \\
\hline & $\mathbf{G}_{\mathbf{3}}$ & $<30^{0}$ (Severe form) \\
\hline \multirow[t]{4}{*}{ Lasegue's sign } & Go & No aggravation in pain \\
\hline & $\mathbf{G}_{1}$ & Mild aggravation in pain on SLR, following foot dorsiflexon \\
\hline & $\mathbf{G}_{2}$ & Moderate aggravation in pain on SLR, following foot dorsiflexon \\
\hline & G3 & Severe aggravation in pain on SLR, following foot dorsiflexon \\
\hline
\end{tabular}

Assessment of overall effect of therapy - The total effect of therapy was assessed considering overall improvement in sign and symptoms as below given criteria:
$\rightarrow$ Maximum improvement / Cured $\quad->75 \%$ im- provement

$\rightarrow$ Moderate improvement - $>50 \%$ to $75 \%$ improvement

$\rightarrow$ Mild improvement - $>25 \%$ to $50 \%$ improvement

$\rightarrow$ Unsatisfactory - Negligible $(\leq 25 \%)$ improvement

Observation - Out of the 35 screened patients, total 30 patients completed the treatment. Maximum, that is, 
$71.43 \%$ of the patients were male, $31.43 \%$ belongs to age group $31-40$ years, and $28.57 \%$ were Labourer and Farmer group. In Prakruti wise distribution of patients, maximum, that is, $45.71 \%$ were of Vata-Kaphaja, followed by $28.57 \%$ were of Sannipataja Prakruti. Gradual onset of disease was found in $68.57 \%$ patients while sudden onset was seen only in $8.57 \%$ patients. Maximum that is, $37.14 \%$ patients had the chronicity of less than one year, followed by $29.41 \%$ patients. Most of the patients i.e. $42.86 \%$ were having Standing nature of work followed by $1028.57 \%$ having Travelling nature of work. $77.14 \%$ were past history of trauma to lumbosacral region. Multiple responses found in Radiological changes. It shows $85.71 \%$ cases of Degenerative changes, $42.86 \%$ cases of reduced disc space L4-L5 or L5-S1, 40\% cases of Spondylosis but no patients in Kyphosis or Loss of lumber lordosis group.

In this study, Low back pain radiating to foot either left / right (Sphik Purva Kati Pristha Uru Janu Jangha Pada Kramat) present in all patients of all group. Other clinical features like Stiffness (Stambha) present in $33.33 \%$ cases, Pricking sensation (Toda) in 43.33\% cases, Twitching (Spandana) in $30 \%$ cases, Heaviness (Gauravata) in $36.67 \%$ cases and Numbness (Suptata) were present in $26.67 \%$ cases of Group - A whereas in Group - B Stiffness (Stambha) present in 30\% cases, Pricking sensation (Toda) in $43.33 \%$ cases, Twitching (Spandana) in 40\% cases, Heaviness (Gauravata) in $36.67 \%$ cases and Numbness (Suptata) were present in $36.67 \%$ cases.

Result - The effect of therapy on cardinal symptoms after treatment shows $57.59 \%$ \& 58.80\% relief in Radiating pain, $54.17 \%$ \& $59.08 \%$ in Stiffness (Stambha), $60.01 \%$ \& 62.08\% in Pricking sensation (Toda), $52.38 \%$ \& $63.99 \%$ in Twitching (Spandana), 60.88\% \& 65.36\% in Heaviness (Gauravata), 64.29\% \& $65.02 \%$ in Numbness (Suptata), 68.96\% \& 71.87\% in Lasegue's sign and $64.44 \% \& 68.29 \%$ in SLR test respectively among Group - A treated with Rasna Guggulu \& Group - B treated with Trayodasanga Guggulu.

\begin{tabular}{|c|c|c|c|c|c|c|c|c|c|c|}
\hline \multicolumn{2}{|l|}{ Sign \& Symptoms } & \multicolumn{2}{|c|}{ Mean Score } & \multirow{2}{*}{$\begin{array}{l}\text { Mean } \\
\text { diff. }\end{array}$} & \multirow{2}{*}{$\begin{array}{l} \pm \\
\text { S.D. }\end{array}$} & \multirow{2}{*}{$\begin{array}{l}\% \text { of im- } \\
\text { provement }\end{array}$} & \multirow{2}{*}{$\begin{array}{l} \pm \\
\text { S.E. }\end{array}$} & \multirow{2}{*}{$\begin{array}{l}\text { w- Value/ } \\
\text { t- Value }\end{array}$} & \multirow{2}{*}{$\begin{array}{l}\text { p } \\
\text { Value }\end{array}$} & \multirow{2}{*}{$\begin{array}{l}\text { Re- } \\
\text { mark }\end{array}$} \\
\hline & & B.T. & A.T. & & & & & & & \\
\hline \multirow[t]{2}{*}{ Radiation of pain } & TG1 & 2.20 & 0.93 & 1.27 & 0.46 & $57.59 \%$ & 0.12 & 120 & $<0.0001$ & E.S. \\
\hline & TG2 & 2.27 & 0.93 & 1.33 & 0.62 & $58.80 \%$ & 0.16 & 120 & $<0.0001$ & E.S. \\
\hline \multirow{2}{*}{$\begin{array}{l}\text { Stiffness } \\
(\text { Stambha })\end{array}$} & TG1 & 2.40 & 1.10 & 1.30 & 0.48 & $54.17 \%$ & 0.15 & 55 & 0.002 & V.S. \\
\hline & TG2 & 2.44 & 1.00 & 1.44 & 0.53 & $59.08 \%$ & 0.18 & 45 & 0.0039 & V.S. \\
\hline \multirow{2}{*}{$\begin{array}{l}\text { Pricking sensa- } \\
\text { tion }(\text { Toda })\end{array}$} & TG1 & 1.92 & 0.77 & 1.15 & 0.38 & $60.01 \%$ & 0.10 & 91 & 0.0002 & E.S. \\
\hline & TG2 & 2.23 & 0.85 & 1.39 & 0.51 & $62.08 \%$ & 0.14 & 91 & 0.0002 & E.S. \\
\hline \multirow{2}{*}{$\begin{array}{l}\text { Twitching (Span- } \\
\text { dana) }\end{array}$} & TG1 & 2.33 & 1.11 & 1.22 & 0.44 & $52.38 \%$ & 0.15 & 45 & 0.0039 & V.S. \\
\hline & TG2 & 2.08 & 0.75 & 1.33 & 0.65 & $63.99 \%$ & 0.19 & 78 & 0.0005 & E.S. \\
\hline \multirow{2}{*}{$\begin{array}{l}\text { Heaviness } \\
\text { (Gauravata) }\end{array}$} & TG1 & 2.09 & 0.82 & 1.27 & 0.47 & $60.88 \%$ & 0.14 & 66 & 0.001 & E.S. \\
\hline & TG2 & 2.36 & 0.82 & 1.55 & 0.69 & $65.36 \%$ & 0.21 & 66 & 0.001 & E.S. \\
\hline \multirow{2}{*}{$\begin{array}{l}\text { Numbness (Sup- } \\
\text { tata) }\end{array}$} & TG1 & 1.75 & 0.63 & 1.13 & 0.35 & $64.29 \%$ & 0.13 & 36 & 0.0078 & V.S. \\
\hline & TG2 & 1.82 & 0.64 & 1.18 & 0.60 & $65.02 \%$ & 0.18 & 66 & 0.001 & E.S. \\
\hline \multirow[t]{2}{*}{ Lasegue's sign } & TG1 & 1.93 & 0.60 & 1.33 & 0.49 & $68.96 \%$ & 0.13 & 120 & $<0.0001$ & E.S. \\
\hline & TG2 & 2.13 & 0.60 & 1.53 & 0.52 & $71.87 \%$ & 0.13 & 120 & $<0.0001$ & E.S. \\
\hline \multirow[t]{2}{*}{ SLR test } & TG1 & 45.00 & 74.00 & 29.00 & 11.98 & $64.44 \%$ & 3.09 & 9.374 & $<0.0001$ & E.S. \\
\hline & TG2 & 41.00 & 69.00 & 28.00 & 12.51 & $68.29 \%$ & 3.23 & 8.671 & $<0.0001$ & E.S. \\
\hline
\end{tabular}

B.T.- Before treatment, A.T. -After treatment, S.D. - Standard deviation, S.E. - Standard error, E.S.- extremely significant, V.S. - Very significant

- Statistical evaluation (The Wilcoxon matchedpairs signed-ranks test of significance for subjective parameters and Paired t-test for objective parameters) shows that the effect of drug on various clinical features in Group - A and Group - B was extremely/very significant. 
- The comparative study on effect of trial drug (The Mann-whitney test for subjective parameters \& Unpaired $\mathrm{t}$ test - with Welch correction for objective parameters) on various clinical features between Group-A and Group-B shows statistically not significant.

\begin{tabular}{|c|c|c|c|c|c|c|}
\hline Symptom & Group & No of pts & Means & $\begin{array}{l}\text { Mann-Whitney } \\
\text { U value/ t - value } \\
\text { (Welch's corrected) }\end{array}$ & p-Value & Remark \\
\hline \multirow[t]{2}{*}{ Radiation of pain } & TG1 & 15 & 1.267 & \multirow[t]{2}{*}{110.5} & \multirow[t]{2}{*}{0.9356} & \multirow[t]{2}{*}{ not significant } \\
\hline & TG2 & 15 & 1.333 & & & \\
\hline \multirow[t]{2}{*}{ Stiffness (Stambha) } & TG1 & 10 & 1.3 & \multirow[t]{2}{*}{38.5} & \multirow[t]{2}{*}{0.5582} & \multirow[t]{2}{*}{ not significant } \\
\hline & TG2 & 9 & 1.444 & & & \\
\hline \multirow[t]{2}{*}{ Pricking sensation (Toda) } & TG1 & 13 & 1.154 & \multirow[t]{2}{*}{65} & \multirow[t]{2}{*}{0.2051} & \multirow[t]{2}{*}{ not significant } \\
\hline & TG2 & 13 & 1.385 & & & \\
\hline \multirow[t]{2}{*}{ Twitching (Spandana) } & TG1 & 9 & 1.222 & \multirow[t]{2}{*}{51.5} & \multirow[t]{2}{*}{0.8483} & \multirow[t]{2}{*}{ not significant } \\
\hline & TG2 & 12 & 1.333 & & & \\
\hline \multirow[t]{2}{*}{ Heaviness (Gauravata) } & TG1 & 11 & 1.273 & \multirow[t]{2}{*}{48} & \multirow[t]{2}{*}{0.3502} & \multirow[t]{2}{*}{ not significant } \\
\hline & TG2 & 11 & 1.545 & & & \\
\hline \multirow[t]{2}{*}{ Numbness (Suptata) } & TG1 & 8 & 1.125 & \multirow[t]{2}{*}{43} & \multirow[t]{2}{*}{0.9383} & \multirow[t]{2}{*}{ not significant } \\
\hline & TG2 & 11 & 1.182 & & & \\
\hline \multirow[t]{2}{*}{ Lasegue's sign } & TG1 & 15 & 1.333 & \multirow[t]{2}{*}{90} & \multirow[t]{2}{*}{0.288} & \multirow[t]{2}{*}{ not significant } \\
\hline & TG2 & 15 & 1.533 & & & \\
\hline \multirow[t]{2}{*}{ SLR TEST } & TG1 & 15 & 29 & \multirow[t]{2}{*}{0.2236} & \multirow[t]{2}{*}{0.8247} & \multirow[t]{2}{*}{ not significan } \\
\hline & TG2 & 15 & 28 & & & \\
\hline
\end{tabular}

Assessment of overall effect of therapy - Looking to the overall effect of treatment at the end of the therapy with Rasna Guggulu (Group A), 20\% patients was get Moderate improvement while $80 \%$ patients were get mild improvement whereas with Trayodashang Guggulu (Group - B), 40\% patients were get Moderate improvement while $60 \%$ patients were get mild improvement.

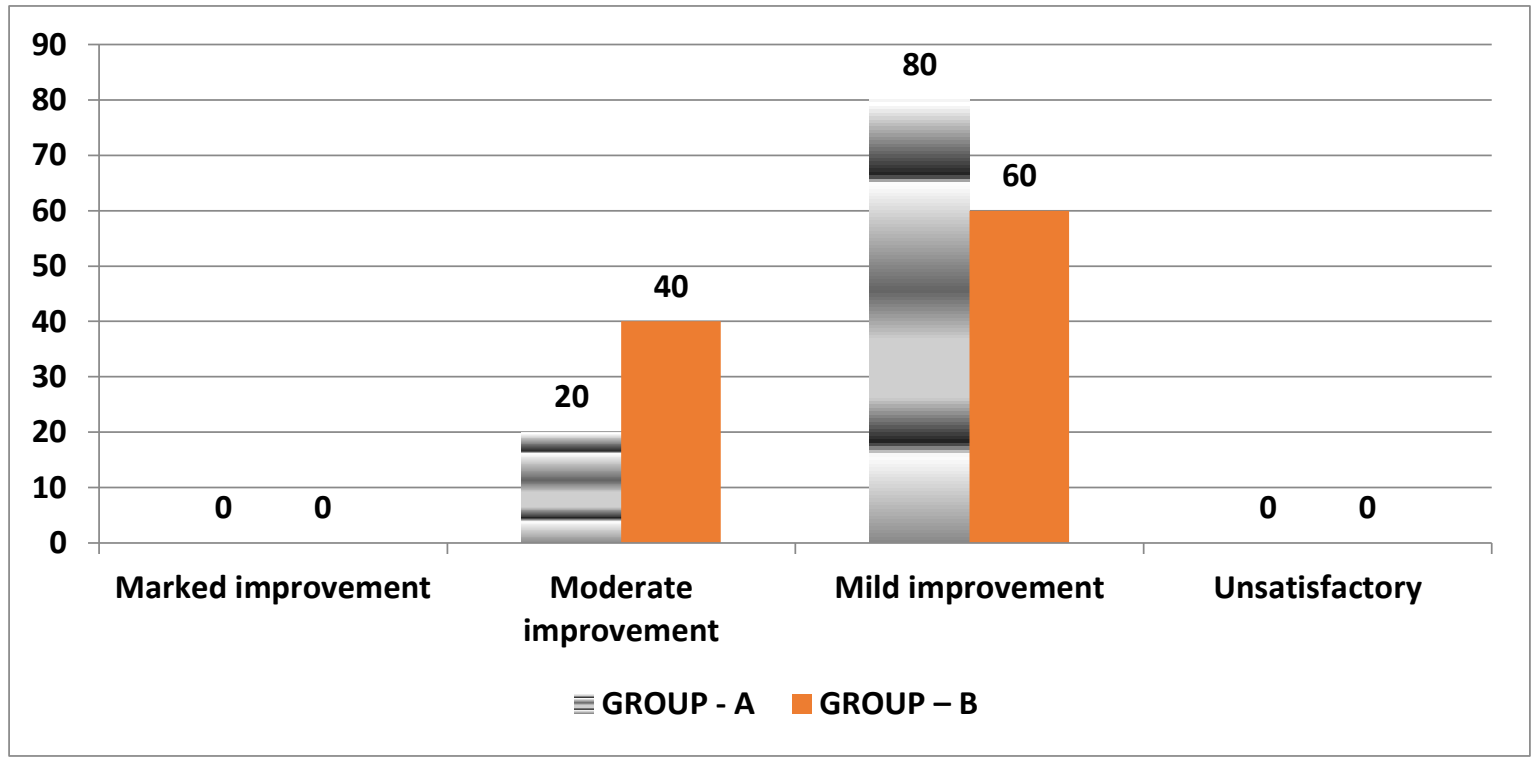




\section{DISCUSSION}

Gridhrasi is a painful condition in which the person can't sit and walk properly that hampers his normal activity. In this study the drug chosen for the study i.e. Rasna Guggulu and Trayodashang Guggulu have textual reference for Gridhrasi as mentioned in Bhaishajya Ratnavali Vatavyadhiadhikar. These are guggul based herbal formulations. Hence provides strength to the nerves, bones, joints, muscles and ligaments.

In the observation more patients found in middle age highlights the workload in the middle age and onwards. This is the beginning of the ageing process and degenerative changes in spine develop at this age. Male predominance highlights the professional exposure to strain. The study reveals that Gridhrasi (Sciatica) can occur among Labourer and Farmer group because they are prone to more physical work such as lifting or carrying heavy objects. Gradual onset in maximum cases shows the pathological basis of the condition lies in degeneration of the intervertebral discs. Due to progressive development of disc degeneration, nerve roots affected gradually and symptoms aggravated day by day. The main reasons for chronicity are lack of awareness towards gravity of condition and unwillingness to avoid causative factors. Presence of trauma / sprain, the discs are subjected to the greatest stress and are most prone to earlier degenerative changes which produce low back pain. After treatment any remarkable or significant changes were not reported in radiological parameters. This is because of the changes in Gambhira Dhatu are permanent and need very long treatment for reversal.

Result shows the Percentage (\%) of improvement was more in Trayodashang Guggulu (Group - B) than Rasna Guggulu (Group A) but as Comparative study shows statistically not significant that means the effect of Trayodashang Guggulu (Group - B) was not so much differ than Rasna Guggulu (Group A) rather the relief provided by both group was nearly similar.

The overall effect of therapy after treatment shows that more patients get better result by Trayodashang Guggulu (40\% patients were getting Moderate improvement) than Rasna Guggulu (20\% patients was got Moderate improvement) but no one in unsatisfactory group.
Hence both the trial drugs, Rasna Guggulu and Trayodashang Guggulu proved to be effective in combating the disease Gridhrasi but comparison on effectiveness of treatment among both the drug Trayodashang Guggulu is more effective than Rasna Guggulu in the management of Gridhrasi (Sciatica).

\section{CONCLUSION}

Gridhrasi (Sciatica) is a condition that arises when sciatic nerve is pressed or gets inflamed. Conventional Medicine and surgery are widely used in the management of sciatica, but the prevalence of sciatica is in progressive state having alarm conditions of morbidity. Disability and costs related to pain, not to the disease process. So, the disease drawing attention for the consideration of research works. Various Guggulus are indicated in ayurveda for this.

Here in this study, A clinical comparative study was done on management of Gridhrasi with Rasna Guggulu and Trayodashang Guggulu to evaluate its therapeutic efficacy.

The study concludes that both Rasna Guggulu and Trayodashang Guggulu proved to be effective in combating the disease Gridhrasi but comparison on effectiveness of treatment among both the drug Trayodashang Guggulu is more effective than Rasna Guggulu in the management of Gridhrasi (Sciatica). The study was carried out on a smaller number of patients for a shorter duration, hence need to be evaluated on a larger number of patients and should be carried out for a longer duration.

\section{REFERENCES}

1. Charak Samhita by Dr. Gorakh Nath Chaturvedi, vol -2, Edited by- Rajeswaradatta sastri, Charak Samhita chikitsa sthan chapter- 28, verse- 15, Edition 2004, published by Chaukhambha Bharti Academy.

2. Charak Samhita by Dr. Gorakh Nath Chaturvedi, vol -2, Edited by- Rajeswaradatta sastri, Charak Samhita chikitsa sthan chapter- 28, verse- 18, Edition 2004, published by Chaukhambha Bharti Academy.

3. Charak Samhita by Dr. Gorakh Nath Chaturvedi, vol -1, Edited by- Rajeswaradatta sastri, Charak Samhita sutra sthan chapter- 20, verse- 11, Edition 2004, published by Chaukhambha Bharti Academy. 
4. Charak Samhita by Dr. Gorakh Nath Chaturvedi, vol -2, Edited by- Rajeswaradatta sastri, Charak Samhita chikitsa sthan chapter- 28, verse- 56-57, Edition 2004, published by Chaukhambha Bharti Academy.

5. Susruta Samhita by Kaviraja Ambikadutta Shastri, vol1, Edited by Ayurveda Tattva Sandipika, Susruta Samhita nidan sthan chapter-1, verse- 74, Edition 2012, published by Chaukhambha Sanskrit Sansthan Varanasi.

6. Bhaishajya Ratnavali, Gobind Das Sen with Vidhyotini hindi commentary by Ambika dutta Shastri, B.R. Vatvyadhiadhikar, verse-43, Edition 1999, published by Chaukhamba Sanskrit Samsthana Varanasi.

7. Bhaishajya Ratnavali, Gobind Das Sen with Vidhyotini hindi commentary by Ambika dutta Shastri, B.R. Vatvyadhiadhikar, verse-89-90, Edition 1999, published by Chaukhamba Sanskrit Samsthana Varanasi.

\section{Source of Support: Nil}

\section{Conflict of Interest: None Declared}

How to cite this URL: Prachi Chaudhary et al: A Clinical Comparative Study On Management Of Gridhrasi (Sciatica) With Rasna Guggulu And Trayodashang Guggulu. International Ayurvedic Medical Journal \{online\} 2021 \{cited February, 2021\} Available from: http://www.iamj.in/posts/images/upload/343 349.pdf 